\title{
A Novel Probe into College English Quality- oriented Transformation Based on the Impersonal Evaluation Criteria of College English Instruction
}

\author{
Xiongyong Cheng \\ School of Foreign Languages, Henan University of Technology, 450001 Lianhua Avenue, Zhengzhou High \& New- \\ tech Industries Development Zone, China
}

\begin{abstract}
Whether a novel teaching module might be realized would lie critically in adaptable teaching evaluations. Establishing a novel and multiple evaluation system is a vital means of measuring students' learning outcomes and regulating students' learning orientation for the sake of truly eliminating traditional education module effects, actually reflecting students' subjectivity of putting people first, and achieving their personalization of learning. As such, this paper raises concerns about the objective criteria of current college English teaching situations based on actual college English teaching circumstances in China, i.e., the criteria of skill cultivation, cognition, and aesthetics, focusing on the criteria of practical application proficiency of college English teaching. Accordingly, the author lists various drawbacks existing in present college English education in order to further reveal the significance of transformation in college English instruction, combining the major reform initiatives of college English test-4/6 (CET-4/6) from the Ministry of Education in response to these drawbacks. On the basis of the analysis, the current paper thus attempts to pose the appropriate corrective action plan by indicating the specific directions of the future quality-oriented transformation in college English regarding further (a) strengthening the cultivation of students' English comprehensive applied competence in listening and speaking, (b) advancing a novel computer- and classroom-based teaching model, (c) reinforcing teachers' training program, and (d) actively and steadily pushing forward the reform of CET4/6 Internet-based tests.
\end{abstract}

Index Terms - college English education, objective evaluation criterion, multiple evaluation system, qualityoriented reform

\section{INTRODUCTION}

It is well known that English has been a global lingua franca (i.e., Globish) with universal application and acceptance (Nunan, 2003; Zhang, 2008). The universality of the global language is characterized with its wide linguistic application as regards rich computer-based wording, high-tech lexicons in addition to daily communicative expressions (Ministry of Education of China [MOE], 2005). It is no wonder that the English language works as an important international working language utilized so popularly around the world (Ouyang, 2000). The latest statistics show that around $93 \%$ of the academic papers and other publications are published in different journals or periodicals and read at various seminars or workshops in English, and furthermore, the Internet is mainly dominated as well by English environment (Zhou, 2013). In particular, when recruiting new staff, enterprises or companies tend to request that college graduate applicants should demonstrate their individual abilities not only in reading and writing in English but also in English listening and speaking (Chen, 2005). The latter would be laid more and more emphasis because, for instance, in joint ventures or foreign-invested firms, oral communicative competence is even more stressed as the first and foremost essential condition(Ye, 2007). On the opposite, college graduate applicants must be really weak at these requests at this exact point (Zhou, 2013). As such, it follows that the current college English teaching program adapts to the demand of objective evaluations and the social development via transformation.

\section{The Evaluation Criteria of College English Instruction (CEI)}

CEI should possess its own assessment criteria upon which college students' actual application proficiency of the language could be scientifically evaluated (Genesee \& Upshur, 1994; MOE, 2005). As college English instruction in China has experienced distinct reform phases at regular intervals, it seem to be compulsory to develop a set of objective criteria for the current college English instruction, which, hopefully, turns out to be a directive guidance to the implementation of college English instructional activities (Zhang, 2008; Zhou, 2013).

\section{A. The Objective Assessment Criteria of CEI}

Nowadays, the fundamental elements of contributing to the quality-oriented education are still at issue ( $\mathrm{Ng} \& \mathrm{Tang}$, 1997). Pursuant to the regulations by the Ministry of Education of China (MOE) and related academic discussion of late, the quality-oriented education as regards CEI is supposed to encompass morality, English language knowledge and 
skills, volitional quality, affective attitude, cultural consciousness, and the sense of aesthetic appreciation and generation of beauty (MOE, 2003). For the sake of organic infusion of the elementary English language quality-oriented education into English language teaching processes, Bloom's educational objective taxology incorporates the cognitive objectives of quality-oriented education into "emotional objective, objective of technical ability cultivation and objective of recognition", and the mix is the "objective of aesthetic appreciation" which embodies the scientific perspective on the basis of the combination of aesthetics and linguistics in the western aesthetics (Bloom, 1997, pp.1-4). As such, attention should be paid to the gradual realization of the above-mentioned targets scientifically in our classroom practices (Black \& William, 1998). When we execute our educational objectives, we should identify the basic functions of controlling instructional contents, channeling instruction, and motivating students' realization of their new objectives in order to guarantee the all-round cultivation of students' basic quality and continuously internalize the objectives as psychological targets (MOE, 2003).

\section{B. The Instructional Requests Issued by the MOE}

Apparently, the Chinese government has been attaching great importance to quality-oriented education of college English (Hu, 2005). As the Teaching Requirements for College English Course newly issued by the MOE (2003) puts it,

a. CEI forms an integral part of higher education, and the college English course is one of the essential compulsory courses. College English teaching, guided by foreign language theories, should focus on English linguistic knowledge, learning strategy, and transnational intercommunication as main contents, and should also be an instructional system by integrating various teaching modes and means.

b. CEI is aimed at the cultivation of students' comprehensive application competence in English, particularly, in speaking and listening, thus enabling them to effectively conduct efficient information communication in spoken and written English in their future work and social contact. (p. 28)

\section{THE DEFECTS IN THE CURRENT CEI}

Nonetheless, the real situation of CEI is far from the proposed requirements of the MOE (Ye, 2007). In practical CEI, it seems that CEI is totally oriented towards preparing the students for CET-4/6 and nothing else (MOE, 2005). If a student can pass CET-4/6 smoothly, everything goes off without a hitch on the part of the students (Rhao, 2002). There might exist a gap between the MOE requirements and EFL teachers' classroom practices in terms of CEI practices, so this paper attempts to fill the gap in the existing literature on the extent of teachers' adherence to MOE requirements in CEI education.

\section{A. Most College Students' Failure in Management with CET-4/6}

The current situation of CEI in most Chinese colleges and universities does have a lot to be desired, but most college students lack passion for English due to both teachers' and students' tunnel vision which hinders their vision (Ouyang, 2000; Shih, 1999). Accordingly, both teachers and students are dissatisfied with the other side and are at loggerheads over the other side's poor performance (Kang \& Wang, 2003). Around 40\% of those college students who take CET exams are up to the average, namely, an inversely proportional percentage of students who can pass CET-4/6 respectively, and some others can only manage with CET exams by flukes and by tricks (MOE, 2005).

\section{B. Inappropriateness of Teacher Roles in CEI Education}

Historically, China is a typically authoritarian country, and the Confucian stratified social hierarchy greatly affects the classroom which is thus featured with teacher-centeredness, textbook-centeredness, and grammar-centeredness (Liao, 2003). Teacher-centeredness implies that the teacher is omnipotent to everything and absolutely controls instructional contents and paces (Adamson, 1995; Ting, 1987). As such, classrooms in China have been dominated by teachers for long who are always standing and talking in front of the blackboard with students sitting in lines to listen and take notes simultaneously (Sun, 2005). The absence of a teacher role as the authority seems inconceivable and dreadful (Medgyes, 1986). In such a context, students are generally ready to look on teachers as the main source of knowledge and are accustomed to speech-dominated education (Cortazzi \& Jin, 1996).

The grammar-translation (GT) method was the earliest approach EFL teachers utilized in China, which focused on grammar instruction via translation and interpretation of rule after rule (Brown, 2001). Nowadays, many students in China seem accustomed to this method and hold strong interest in learning English grammar, for most of them perceive that if they understand this system, it would help them apply English more effectively (Harvey, 1985).

Another teaching approach applied is the direct method, which views language as a skill or habit to be achieved by repetition and imitation (Ye, 2007). The execution of the direct method is effective in small-size classes, which is applicable to EFL beginners but inappropriate in populous China (Ye, 2007); in conducting it, the teacher role in the classroom does not change radically compared with the teacher as knowledge-giver or transmitter in the previous grammar-translation method.

In the early 1990's, the communicative language teaching (CLT) approach was introduced in China, which is aimed at encouraging students to use language as a medium in communication (Li, 1984; Ye, 2007; Yu, 2001). Not only do teachers cultivate students' integrated English skills, they also foster their abilities of applying these skills in authentic settings (Ye, 2007). Galloway (1993) asserts that CLT can make students moderately tense in the case of the 
consequence of classroom activities which result in various reactions and responses. In the CLT process, teachers usually perform the roles of facilitator, adviser, and co-communicator who facilitate communication in EFL, monitor student performance, and engage in communicative activities together with students (Johnson \& Morrow, 1981). To Ye's (2007) thinking, CLT implementation has been constrained by lots of factors, the two major ones being: (a) that the textbook designed for CLT breaks up the integrity of the English language, thus adding to students' difficulty in learning EFL; and (b) that the teacher roles played in this approach are hard to assess.

In the last few decades, EFL teachers have turned to the audio-lingual approach that tends to stress listening and speaking by utilizing sentence patterns as the bottom of instruction and attempting to avoid the native language (Ye, 2007). The EFL teacher role attempts to be the organizer of students' mechanical imitation activities rather than the cultivation of English skills, causing the insufficiency of students' flexibility in learning and competence of reading and writing (Ye, 2007).

Thus, any attempt from a teacher for such simulated interactions in the classroom as pair-work, group-work, teamwork, game-plays, and communicative tasks would run the risk of resistance or even resentment from students (Adamson, 1995; Chen, 2005; Li, 1996). Though numerous EFL teachers have tried to alter dominant processes in the classroom, they fail due to frustration, losing their initiatives and acquiescing to traditional practices (Campbell \& Zhao, 1993). In the teacher-centered class, there is no exchange of information since the teacher is always the master while students are passive receivers rather than active participants (Yang, 2003). Consequently, their teachers teach what is tested, and they would learn what is examined only (Kang \& Wang, 2003; Li, 1996; Ting, 1987; Zhou, 2013).Teachers thus experience a special EFL instructional mode which is "time-consuming and less effective" (Li, 1996, p. 14). This sort of teacher-centeredness generates the typical environment of keen competition in lieu of cooperation so that lowachievers would be left behind eventually (Richards \& Rodgers, 2000).

\section{Bilateral Dissatisfaction from Teachers and College Students}

Under such circumstances and situations, there really appears to be a pair of contradictions between teachers and students either side of whom is satisfied with the other side, with students accusing their English teachers of not being worth their salt, not performing well enough, thus leading them nowhere (Hu, 2002; Hu, 2005; Liao, 2004) . Likewise, English teachers scold the students for being lax in their moral virtues and discipline and just frittering away the precious time for fun without devoting sufficient time and energy to learning English or just fooling around at college and falling short of their parents' expectations (Campbell \& Zhao, 1993).

\section{Cheating in CET-4/6 Running Amuck in Many Places}

And what is even worse, cheating in English exams or even in CET exams runs so wild on the campus for those who are lacking in the fundamental competence in passing CET-4/6 (Cortazzi \& Jin, 1996; Ting, 1987; Zhou, 2013). Some of them even engage well-paid "ringers" to sit in for the exams in their favor at the high expense (Rhao, 2002; Sun, 2005). This kind of phenomenon is bound to badly wreck the regular college English education and sets a negative example to those who are devoted to serious learning of English (MOE, 2003, 2005).

In the end, more and more college students are reluctant to exert all efforts to prepare themselves for CET-4/6 exams, which tends to take the exam-takers a couple of months to delve into the drag preparation by doing simulated or synchronous exercises concerned for the sake of higher scores in grading (Huang \& Xu, 1999; Liao, 2004; Nunan, 2003). Though some students go all out for the exams in every possible means, they still fail in the exams at the end, which brings about more and more students getting tired of their English lessons and gradually putting it aside and going in for something funnier on the campus (Li, 1996; Yu, 2001).

\section{E. College English Teachers' Lack of Passionate in Conducting Lessons}

Simultaneously, college English teachers also get puzzled at the situation they are faced with (Adamson, 1995; Campbell \& Zhao, 1993). They claim that the students deviate from the essential requests in their English learning mainly because there are too many temptations on the campus like campus love and campus cyber bars open 24 hours a day, seven days a week, attracting numerous college students who show no interest in their lessons, English included (Ng \& Tang, 1997; Zhou, 2013). Likewise, they argue that the students who lag behind in academic achievements are unwilling to cooperate with their teachers in the classroom, and accordingly, in such a vicious circle, the teachers also lack enthusiasm and only do their routine English teaching perfunctorily without strictly following the curriculum issued by the MOE (MOE, 2003, 2005; Nunan, 2003; Ye, 2007).

To sum up, the current college English instruction (CEI) does leave so much to be desired and the CEI teachers are supposed to take the initiative to channel CEI onto the right track and gradually bring into effect the above-mentioned CEI objectives and functions (Zhou, 2013). As such, it seems to be indispensable for CEI teachers to make all potential exertions to transform the current CEI education style, without which we would proceed to waste many educational resources in CEI education (MOE, 2005). Influenced by the present English teaching configuration, most college students would be thinking that they are forcefully required to learn this monstrous lingua franca but make no substantial progress with over ten years' time wasted in learning the horrible language (Adamson, 1995). In order to adapt to the need of society, it is high time for and CEI teachers and corresponding educators to transform the current 
outdated CEI education module, and they really have no time to procrastinate in this regard (Ouyang, 2000; Yang, 2003).

\section{QUALITY-ORIENTED COLLEGE ENGLISH INSTRUCTION}

Although CEI in China has made outstanding achievements since the commencement of the reform and opening in 1978, there exist still numerous new problematics cropping up in a sense (Yang, 2000). Pursuant to some scholars and experts, CEI teachers are embarrassed with the situations of current college English learning and teaching in that there still exist lots of flaws and bugs in this very respect like the imbalance and low level of CEI, which renders more emphasis on knowledge but less emphasis on practical competence (e.g., Adamson, 1995; Cortazzi \& Jin, 1996; Nunan, 2003; Shih, 1999; Yang, 2000). Students learned English grammatical structures and rules by rote, but they could not apply them in authentic contexts flexibly in a natural way (Widdowson, 1990). Students have become strong in grammatical structures but weak at communication competence even after numerous years of learning English (Ye, 2007) in that this case lays little emphasis on the learning of communicative skills and is viewed as generating "deaf and dumb" (Longzi, Yaba) (Ng \& Tang, 1997, p. 68). As such, it seems indispensable to transform the present college English instruction into quality-oriented education for the sake of adaptation to the requirements of society.

\section{A. College English Transformation Adapting to the Right Track}

The urgent mission for college EFL teachers and educators to carry out is to transform CET-4/6 thoroughly, which is an effective push for CEI to be appropriately channeled onto the right track in terms of students' communicative faculty in verbal and literal English (MOE, 2005). It goes without saying that this kind of transformation would have a positive impact on today's college English teaching and learning (Chen, 2005). Specific measures will be taken to assure the smooth execution of the newly published the Project of the Teaching Quality and Teaching Reform of Higher Education (hereafter referred to as Project) designed on "Guidelines for the Curriculum Reform of Higher Education" since the "project designed in 1992 was felt to be inadequate in a number of ways" (MOE, 2005, p. 3). It was completed and issued in the middle of 2001, and from 2002 on, one or more colleges or universities in each province were chosen as trial districts for the new Project where the pilot colleges or universities applied their own coaching instructional materials (MOE, 2005). The proposed reform went through two phases, from completing the initial design, trial, and revision of the new national Project during the 2001-2003 period to gradually expanding new practices throughout China around 2012 (MOE, 2005). Now, the implementation of the new Project is in process all over the country before another new circle of Project reforms for higher education is made known. To all intents and purposes, transformation is established to foster college students' perfect oral English for efficient communication on special occasions (Ellis, 1996; Rhao, 2002; Ye, 2007). The realization of such targets, however, shall surely be supported by modern multimedia resources available (Zhou, 2013).

\section{B. The Necessity and Importance of CET-4/6 and Transformation}

Anyhow, CET-4/6 has taken root in college English instruction in China and played an important part in pushing forward CEI implementation even if it has the defects of its qualities (MOE, 2005). Nonetheless, it is inappropriate to carry out drastic reforms on CET-4/6, for, after all, it has already established itself as an advantageous brand in China's exam system for the past 20 years or so (MOE, 2005). Most probably, there is no better exam evaluation system that can take the place of CET-4/6 (Genesee \& Upshur, 1994). Accordingly, it seems more feasible for the MOE to retain the main skeleton of CET-4/6 with minor alternation, but more emphasis should be laid on changes in contents of the test paper which shall shed luster on CET-4/6 as regards the more rational and scientific allocation of such test configurations like listening, speaking, reading, writing, and translation with heavier emphasis on listening focus and speaking in particular (MOE, 2005, Yang, 2003).

\section{Specific Reformative Initiatives to Be Taken in College English Education}

The Ministry of Education (MOE) is transforming the bachelor-level public English education, figuratively, to cleanse the Augean stables from three aspects.

1) The new issue of college English teaching syllabus: In the first place, the MOE (2005) has determined to modify the current college English syllabus, shifting the testing center from reading comprehension to listening focus. In such cases, importance would be attached to students' functional communication which can facilitate the students' devotion to listening to received English recording or radio programs (Ye, 2007).

A dominant approach to CEI is grammar-centeredness where students are required to center on reading and writing in English via grammar-based translation at the cost of listening and speaking (Chen, 2005). The principle of grammartranslation is to make students exposed to literacy materials and get them ready to change the target language into another language (e.g., mother tongue), and when this approach is utilized, the written form of the target language is given more attention than the spoken language (Larsen-Freeman, 2000). This phenomenon seems to go against the current tendency of EFL instruction, for the competence of oral English communication in international trade is equally or even more important than being able to read and write it due to the economic development of the global scope and the rise of the information technology era (Chen, 2005). 
The implementation of grammar-centered instruction is influenced by the designated instructional curriculum orientations since entrance exams to the postgraduate programs (i.e., MA \& PhD levels) in addition to CET-4/6 are mainly based on the memory of grammatical principles (MOE, 2005). Teaching without predetermined text books is not really teaching in China (Chen, 2005; Liao, 2003, 2004; Ye, 2007). Chinese college students prefer to rely on textbooks while learning, which is their fundamental characteristic (Cortazzi \& Jin, 1996) since "students hold that if they acquire what the textbook contains, they will meet all needs from the teacher and various exams" (Zhang, 2008, p. 49). As a result, Chinese college students tend to enjoy rote learning and therefore lack intellectual initiative (Cortazzi \& Jin, 1996; Wedell \& Liu, 1995). And after working hard for more than a decade under such a teaching module, the students are trained to memorize words and grammatical rules by rote without practical competence to manage well enough in their daily communication with a native speaker (Nunan, 2003; Shih, 1999; Yang, 2003).

2) The necessity of the modification of the current CEI mode: In the second place, reforming the current teaching mode mainly from passive to initiative stresses individual ability in comprehensive application of English (MOE, 2003). Under such circumstances, both teachers and students need to cooperate for more effective and efficient information exploration via practically interactive and mutually beneficial instructional methods (MOE, 2005). Apparently, most college English teachers are short of innovation in their teaching work mainly due to their rejection of novel things that spring up like spring bamboo shoots, such as the Internet, multimedia, and some other modern high-tech inventions (Ouyang, 2000; Yang, 2003; Zhou, 2013). As such, the previous and ongoing conventional teaching methodologies are supposed to make room for cutting-edge instructional ideations (MOE, 2005).

3) CEI embedded in the media-based environment: In the third place, it is widely known that young college students brought up in the high-tech environment are totally immersed in this lifestyle, but their teachers in class tend to bring them back to boring sermons and rote memorization (Zhou, 2013). The young students commence to lose interest in this sort of instructional method with the passage of time, which would assuredly impact on their learning initiatives (Richards \& Rodgers, 2000). Accordingly, it is high time for college English teachers to generate a learner-friendly environment through innovative instructional methods that would apply to their current lifestyle and favors (Hu, 2005). The establishment of such cozy instructional atmosphere would contribute greatly to arouse the enthusiasm of young learners in that the students perceive what the teachers have done to be adaptable to their individual tastes (MOE, 2003). Simultaneously, great emphasis is placed on college students' oral English and listening competence even in the current syllabus and curriculum, but, in most cases, the adolescent college students are exposed to Chinglish uttered by the majority of the Chinese English teachers who have never obtained any opportunity to expose themselves to Received Standard English or experienced no encounter with a native speaker (Nunan, 2003; Ouyang, 2000; Shih, 1999).

4) The alteration needed of the assessment criteria of CET-4/6: In the fourth place, it seems to be significant to transform the present assessment criteria of CET-4/6 from the original emphasis on evaluation of grammar and vocabulary to reading and listening comprehension (MOE, 2005). Undoubtedly, grammar and vocabulary learning is likewise critical during the course of English learning, which, however, should not be overstressed as it has been now (Black \& William, 1998). In the CET-4/6 testing papers, the score allocation of the listening and reading sections can be increased, which, in particular, ought to become a positive reflection on routine teaching and learning activities (MOE, 2005). As such, the teachers will have to impart fundamental skills and techniques of reading and listening to their college students in class since the CET-4/6 testing system is bound to be a baton of students' self-learning (MOE, 2003). Of late, no few statistical surveys show that basic listening is unknowingly neglected by most teachers and students in a variety of colleges and universities (Zhou, 2013). It is no wonder that most CET-4/6 exam-takers are reduced to a nonplus when they are required to listen to the native speakers as luck would have it (Campbell \& Zhao, 1993).

5) Practical reform consequence of CEI as a conducive push to China's economy: The transformation of CET-4/6 is developing steadily, and its positive consequence has already taken shape (MOE, 2005). The Ministry of Education has announced its measures respecting a series of CEI transformation, especially, the transformation of CET-4/6, drawing widespread attention from all the fields of society all over China (MOE, 2003, 2005). Nevertheless, when we discuss the transformation of CEI, we are not referring to the reform of CET-4/6 only, which, in truth, gets involved in the whole process of CEI (Zhang, 2008). As a result, the reform of CEI and CET-4/6 has to be serious and cautious which concerns the interests of every single college student (MOE, 2005). Therefore, not a few educational specialists and educators assert that this type of transformation is oriented toward the correct track concerned that surely will become another landmark in the process of the educational reform of China (e.g., Adamson, 1995; Black \& William, 1998; Ting, 1987; Yu, 2001; Zhang, 2008). On a larger scale, this new round of transformation would more greatly contribute to the facilitation of young college students' practical competence of comprehensive English, which is of epoch-making value to our social development and in-depth transformation of higher education (MOE, 2005).

\section{CONCLUSION}

In conclusion, China's college English syllabus has chiefly experienced three phases of reform. The grammarcentered syllabus was firstly changed to communication-centeredness, which was eventually developed into listeningspeaking-centered transformation. Reviewing the process of CEI reform in China, we are to see clearly that the transformation orientation of CEI is geared to actual application competence. Nonetheless, most college EFL teachers still prefer the grammar-translation strategy. Hopefully, it is assumed that this study could push the current 
transformation of college English education throughout China for the purpose of theoretical verification of students' allround development. As such, the transformation of college English teaching should not overlook the innovative teaching module on the basis of modern multi-media like the Internet, computers, teaching software, and some other effective and efficient instructional devices and means. The multimedia-based teaching environment would contribute greatly to the cultivation of the actual application faculty of college students in that the configuration and interface of the media-based instructional atmosphere could foster adolescent English learners' initiatives to learn even more efficiently. The present transformation of CEI would hopefully contribute to the shift of today's college public English teaching in China from exam-oriented education to quality-oriented education by providing reference evidence for policy makers, curriculum developers, and educators. As the transformation runs deeper in the long run, we can naturally realize the dream that each and every Chinese person is able to speak English as required.

\section{REFERENCES}

[1] Adamson, B. (1995). English in the People's Republic of China: Curriculum continuity and change. Proceedings of the International Curriculum Conference on Partnership in Curriculum Development: Towards More Effective Learning (pp. 230236).

[2] Black, P., \& William, D. (1998). Assessment and classroom learning. Assessment in Education, 1998, 5 (1), 70-74.

[3] Bloom, B. (1997). The educational objective taxology, English Today, 7(5), 1-9.

[4] Brown, H. D. (2001). Principles of language learning and teaching. Beijing: Foreign Language Teaching and Research Press.

[5] Campbell, K., \& Zhao, Y. (1993). The dilemma of English language instruction in the People's Republic of China. TESOL Journal, 2(4), 4-6.

[6] Chen, M. L. (2005). The effect of the cooperative learning approach on Taiwanese ESL students' motivation, English listening, reading and speaking competences. Unpublished doctoral dissertation, La Sierra University, California. Retrieved February 12, 2008, from http://proquest.umi.com

[7] Cortazzi, M., \& Jin, L. (1996). English teaching and learning in China. Language Teaching, 29(1), 61-80.

[8] Ellis, G. (1996). How culturally appropriate is the communicative approach? ELT Journal, 50(3), 213-218.

[9] Galloway, A. (1993). Communicative language teaching: An introduction and sample activities. Center for Applied Linguistics, ERIC Digest (June). Retrieved November 12, 2007, from http://www.cal.org/resources/digest/gallow01.html.

[10] Genesee, F., \& Upshur, J. A. (1994). Classroom-based evaluation in second language. Beijing: Foreign Language Teaching and Research Press.

[11] Harvey, P. (1985). A lesson to be learned: Chinese approach to language class. ELT Journal, 39(3), 183-186.

[12] $\mathrm{Hu}, \mathrm{G}$. (2002). Potential cultural resistance to pedagogical imports: The case of communicative language teaching in China. Language, Culture and Curriculum, 15(2), 93-105.

[13] Hu, G. (2005). "CLT is best for China" - an untenable absolutist claim. ELT Journal, 59(1), 65-68.

[14] Huang, Y., \& Xu, H. (1999). Trends in English language education in China. ESL Magazine, 39(6). Retrieved March 17, 2005 from http://www.eslmag.com/modules.php?name =News\&file=article\&sid=32.

[15] Johnson, K., \& Morrow, K. (1981). Communication in the classroom. London, UK: Longman.

[16] Kang, S. M., \& Wang, X. M. (2003). Improve college English teaching with multimedia. Retrieved December 23, 2012, from http://www.etc.sjtu.edu.cn/zazi/paper/04101/04157.html.

[17] Larsen-Freeman, D. (2000). Techniques and principles in language teaching (2nd ed.). Oxford, UK: Oxford University Press.

[18] Li, L. (1996). On the teaching reform of college English. Paper presented at the conference on teaching in Beijing, China.

[19] Li, X. (1984). In defense of the communicative approach. ELT Journal, 38(1), 2-13.

[20] Liao, X. (2003). Chinese secondary school teachers' attitudes towards communicative language teaching and their classroom practices. Unpublished doctoral dissertation, University of Auckland, New Zealand. Retrieved February 12, 2008, from http://proquest.umi.com.

[21] Liao, X. (2004). The need for communicative language teaching in China. ELT Journal, 58(3), 270-273.

[22] Medgyes, P. (1986). Queries from a communicative teacher. EFL Journal, 40(2), 139-144.

[23] Ministry of Education of China. (2003). Non-English major college English teaching syllabus. Beijing: People's Educational Press.

[24] Ministry of Education of China. (2005). Reform resolutions of CET bands 4 and 6. Beijing: Beijing Normal University Press.

[25] Ng, C., \& Tang, E. (1997). Teachers' needs in the process of EFL reform in China: A report from Shanghai. Perspectives, 9(1), 63-85.

[26] Nunan, D. (2003). The impact of English as a global language on educational policies and practices in the Asia-Pacific region. TESOL Quarterly, 37(4), 589-613.

[27] Ouyang, H. (2000). One-way ticket: A story of an innovative teacher in mainland China. Anthropology and Education Quarterly, 31(4), 397-426.

[28] Rhao, Z. (2002). Chinese students' perceptions of communicative and non-communicative activities in EFL classroom. System, $30(1), 85-105$.

[29] Richards, J. C., \& Rodgers, T.S. (2000). Approaches and methods in language teaching. Foreign Language Teaching and Research Press. Beijing, China: Foreign Language Teaching \& Research Press.

[30] Shih, M. (1999). More than practicing language: Communicative reading and writing for Asian settings, TESOL Journal, 8(4), 20-25.

[31] Sun, J. F. (2005). Evaluation on EFL teachers' roles from the perspective of social constructivism. Unpublished master's thesis, Henan Normal University, China.

[32] Ting, Y. (1987). Foreign language teaching in China: Problems and perspectives. Canadian and International Education, 16(10), 48-61. 
[33] Wedell, M., \& Liu, R. (1995). Language teaching \& learning from theory to practice. Beijing, China: High Education Press.

[34] Widdowson, H. G. (1990). Aspects of language teaching. Oxford, UK: Oxford University Press.

[35] Yang, Y. (2000). History of English education in China. ERIC Microfiche No. ED441347, 1-29.

[36] Yang, Z. (2003). Teacher professionalism and professional development of EFL teachers in China. Retrieved October 6, 2009, from http://www.tefl-china.net/2003/ca13425.htm.

[37] Ye, J. (2007). Adapting communicative language teaching approach to China's context. Sino-US Teaching, 4(10) (Serial No. 46), USA.

[38] Yu, L. M. (2001). Communicative language teaching in China: Progress and resistance. TESOL Quarterly, 35(1), 194-198.

[39] Zhang, W. M. (2008). In search of English as a foreign language (EFL) teachers' knowledge of vocabulary instruction. Unpublished doctoral dissertation, Georgia State University. Retrieved February 12, 2009, from http://etd.gsu.edu/theses/available/etd-05232008-215235/unrestricted/zhang_weimin_200808_phd.pdf.

[40] Zhou, L.X. (2013).Use modern information technology properly and open up English teaching resources. (n.d.). Retrieved December 28, 2013, from http://resource.ahedu.cn_22.html.

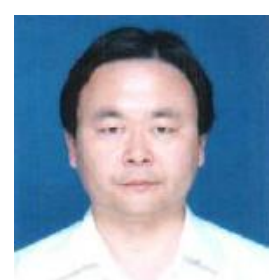

Xiongyong Cheng was born in Xinyang, China in 1966. He is an associate professor in teaching English as a Foreign Language (EFL) at the School of Foreign Languages, Henan University of Technology, China. His primary research interests are EFL testing and assessment in relation to classroom instruction. He holds an MA in Teaching English as a Foreign Language (TEFL) from Henan Normal University, China, and a PhD in Teaching English as a Second Language (TESL) from the University of Malaya, Malaysia.

His current research interests encompass EFL teaching, inter-cultural communication, teacher education, professional development, and the evaluation of curriculum implementation. Assoc. Prof. Dr. Cheng was awarded the honor title "National Excellent Education Gardener" by the Ministry of Education of China in 1993. 